\title{
Association of Dietary Factors with Presence and Severity of Septal Deviation: Results of the Korean National Health and Nutrition Survey 2010-2012
}

\author{
Chun Han, Sang Man Park, Ju-Shin Lim, and Jang-Woo Kwon \\ Department of Otorhinolaryngology-Head and Neck Surgery, Yonsei University Wonju College of Medicine, Wonju, Korea
}

한국인의 영양소 섭취와 비중격 만곡증과의 상관관계: 한국 국민건강영양조사 2010 2012

한 준 · 박상만 · 임주신 · 권장우

연세대학교 원주의과대학 이비인후-두경부외과학교실

Received January 27, 2017

Revised June 22, 2017

Accepted July 4, 2017

Address for correspondence

Jang-Woo Kwon, MD

Department of Otorhinolaryngology-

Head and Neck Surgery,

Yonsei University Wonju

College of Medicine,

Wonju Severance Christian Hospital,

20 Ilsan-ro, Wonju 26426, Korea

Tel $+82-33-741-0642$

Fax $+82-33-732-8287$

E-mail kjw1979@yonsei.ac.kr
Background and Objectives The data of Korean National Health Survey from 2010 to 2012 were used to analyze the correlation between the westernized dietary style with the incidence of septal deviation in the Korean population.

Subjects and Method A total of 25532 candidates between the ages of 13-97 was analyzed with their nutrition uptake, body characteristic differences, and the incidence of septal deviation. Inclusion criteria for the candidate were normal values for the smell test, no rhinological abnormalities, and patients who underwent all of the otolaryngologic examinations. Nutrition uptake of the following was examined: total energy uptake per day (kcal), total daily uptake of food, carbohydrate, protein, fat, water (g), total daily uptake of fiber, potassium, calcium, phosphate, iron, and sodium (mg). Each category was examined, compared, and analyzed to investigate a possible relationship with the incidence of septal deviation.

Results When height, waist, and body mass index (BMI) were categorized according to sex and analyzed for relationship with the incidence of disease, the male group showed a positive correlation with the incidence of septal deviation in all three factors. BMI, an important clinical predictive factor for physical growth, showed a positive relationship for obesity rate and septal deviation with the males aged between 10 and 20 .

Conclusion Males in their 10's and 20's are the most affected by the westernized diet change; therefore, we believe that this is the reason for this age group's association with a higher septal deviation incidence rate compared to other age group

Korean J Otorhinolaryngol-Head Neck Surg 2018;61(1):24-8

Key Words Body mass index · Nasal septum ·

National health and nutrition examination survey.

\begin{abstract}
서 론
이비인후과 클리닉에서 환자들이 호소하는 대표적인 증상 에는 비폐색과 비루 등이 있는데 이들은 주로 만성 비부비동

This is an Open Access article distributed under the terms of the Creative Commons Attribution Non-Commercial License (http://creativecommons.org/licenses/by-nc/4.0) which permits unrestricted non-commercial use, distribution, and reproduction in any medium, provided the original work is properly cited.
\end{abstract}

염(chronic rhinosinusitis), 알레르기성 비염(allergic rhinitis) 그리고 비중격 만곡증(nasal septum deviation)을 지니고 있 을 시 많이 발생한다.,2) 이러한 증상을 야기시키는 질병 중 한 가지인 비중격 만곡증은 비교적 흔한 질환으로서 선천성 혹 은 발달성 기형, 출산주형설, 후천성 혹은 외상성 기형 그리고 비강 내 구조물의 오랜 압박 등으로 인해 발생한다고 하지만 뚜렷한 원인을 알 수 없는 경우도 많다. ${ }^{3)}$ 이 질환은 전 세계적 
으로 서양인에게서 동양인보다 유병률이 높은 것으로 알려져 있는데 적게는 $34 \%$ 에서, 많게는 약 $89.2 \%$ 까지 유병률이 보고 되고 있고 한국인에서는 $48 \%$ 정도로 보고되고 있다. ${ }^{4,5)}$ 이러 한 비중격 만곡증은 최근의 연구에 따르면 앞에서 언급한 원 인들 말고도 환경, 인종, 나이 등에 따라서도 유병률의 차이가 있다고 알려져 있는데, 본 연구에서는 그중 환경에 속하는 영 양 섭취와의 관련성을 분석해보고자 하였다. Chronic rhinosinusitis 및 Allergic sinusitis의 발병률은 이미 미국의 연구 결과 따라 obesity 증가와 양의 상관관계를 보인다고 발표가 되 어져 septal deviation도 영양학적으로 연관성에 대해 살펴 볼 필요가 있다. ${ }^{6)}$ 영양 섭취는 실제적으로 성장에 있어 직접 적으로 영향을 미치는 중요한 인자 중 한 가지로써 우리나라 에서는 특정 기간 동안 식단의 변화가 있었다. 특징적인 점은 지난 1960 1970년대 산업화 및 근대화를 이룩하면서 섭취 하는 식단의 양과 섭취 속도 그리고 주 영양소군이 이전과 많 이 바뀌었다는 것이다. 조금 더 자세하게 다뤄보자면 곡류 섭 취가 1999년 이래 지속적으로 감소하는 경향을 보이고 있고, 동 물성식품 섭취 비율이 1960 1970년대의 비율인 3\%에서 2016 년 현재 20\%대로 크게 증가되었고, 또한 육류 및 우유류 섭 취량 증가로 인해 지방으로부터 섭취하는 1 일 총 에너지의 비 율이 7 18\%로 크게 증가하였다. ${ }^{7)}$ 이러한 변화는 총 에너지와 지방의 섭취량 증가, 탄수화물의 섭취량 감소로 요약되며 다 른 나라에서와 마찬가지로 점차 식단이 서구화되어 간다는 것 을 나타내고 있다. ${ }^{8)}$ 따라서 본 연구에서는 2010 2012년 총 3 년 동안 한국인을 대상으로 시행한 국민건강영양조사 자료를 이용하여 비중격 만곡증과 서구화된 식습관으로 인해 변화된 영양소 섭취 행태 사이의 관련성을 분석해보고자 하였다.

\section{대상 및 방법}

\section{대 상}

국민건강영양조사 제5기 3차 연도 시행한 조사로 2010 2012 년 총 3년간 25533명을 대상으로 국민건강영양조사(승인번호 제11702호)가 이루어졌고, 이 자료를 토대로 후향적으로 분석 되었다. 검사가 비교적 협조적으로 이루어진 만 13세 이상의 사람들 중에서 이비인후과적인 검사 및 영양 섭취 관련 설문 에 참여한 사람들이 조사군에 포함되었다. 2010년에는 8956명, 2011년에는 8518명, 2012년에는 8058명으로 총 25532명 중에 서 이비인후과적 조사와 관련된 이학적 검사가 이루어지지 않 거나, 13 세 미만의 조건에 포함되는 5849명을 제외한 19685 명 이 실제적으로 분석되었다. 이 중 남자는 8636명, 여자는 11049 명이 포함되었다(Fig. 1). 비중격 만곡증에 대한 평가는 2010 2012년도 이비인후과 전공의에게 검사받은 결과로 비강 내 수 축제를 도포 후 비경을 이용해서 양쪽 비강 내를 관찰하여 비 중격 좌우대칭 여부 및 $\mathrm{C}$ 형와 $\mathrm{S}$ 형을 판단하여 비중격 만곡증 으로 정의하였다(한국 국민건강영양조사). 관련성을 분석하 기 위해 포함된 조사의 항목은 신장 $(\mathrm{cm})$, 허리둘레 $(\mathrm{cm})$, 체질 량지수 $\left(\mathrm{kg} / \mathrm{m}^{2}\right)$ 가 분석되었고, 영양소는 1 일 총 에너지 섭취량 (kcal), 그리고 1일 총 식품, 탄수화물, 단백질, 지방, 수분 섭취 량 $(\mathrm{g})$ 및 1 일 총 식이섬유, 칼륨, 칼슘, 인, 철, 나트륨 섭취량 $(\mathrm{mg})$ 이 분석되었다.

\section{분 석}

본 연구는 national database를 cross-sectional로 후향적 으로 분석되었으며, 데이터는 평균평균의 표준 오차 방식으 로 표현하였다. 데이터는 SAS 9.2 Ver.(SAS Inc., Cary, NC, USA) 프로그램을 이용하여 범주형 변수는 Mantel-Haenszel

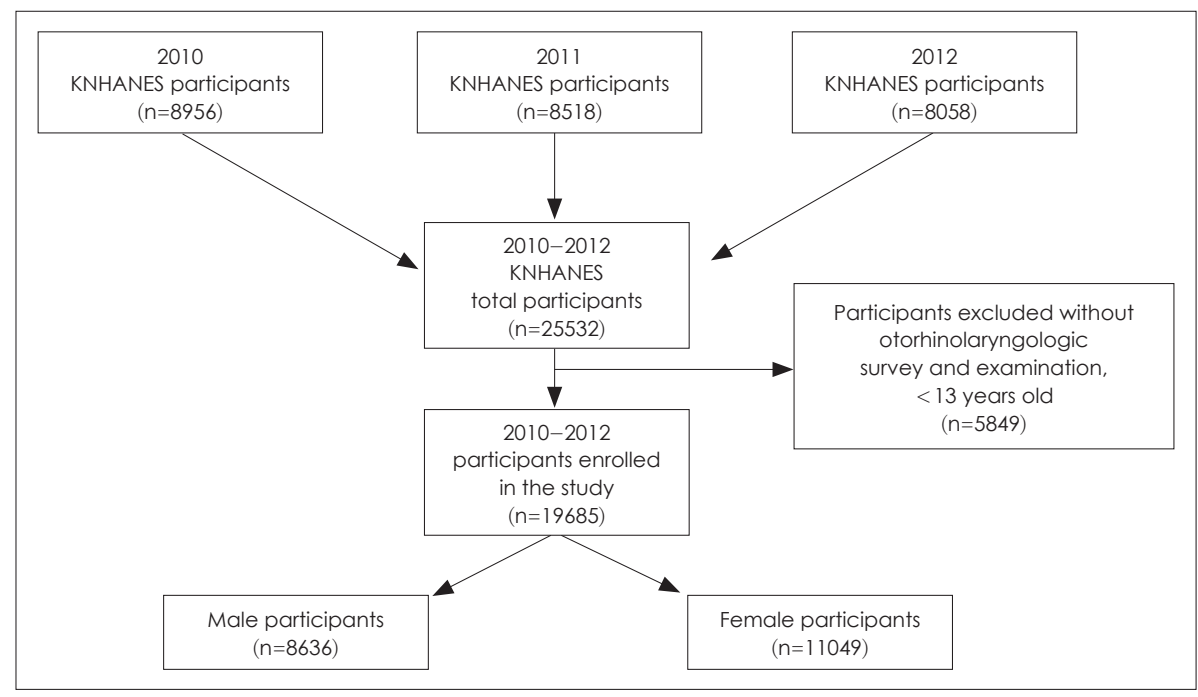

Fig. 1. Enrolled study population from the KNHANES 2010-2012. KNHANES: Korean National Health and Nutrition Examination Survey. 
$\chi^{2}$-test를, 2 가지 그룹 간의 차이는 t-test를 이용하여 분석하 였으며 $p<0.05$ 의 수치를 통계적으로 유의한 것으로 하였다.

\section{결 과}

실제로 등록된 19685명의 조사군 중 남자(43.8\%), 여자 (56.1\%) 비율은 거의 비슷하였으며 그중에서도 비중격 만곡 증 유병률은 거의 비슷한 정도(24.9, 22.6\%)를 보여주고 있었 다(Table 1).9) 이에 관련 변수들을 포함하여 위와 마찬가지로 성별을 기준으로 나누어 분석했을 시 남자군에서 비중격 만 곡증을 가지고 있는 경우가 비중격 만곡증이 없는 경우와 비 교했을 때 키 $(\mathrm{cm})$, 허리둘레 $(\mathrm{cm})$, 체질량지수 $\left(\mathrm{kg} / \mathrm{m}^{2}\right)$ 가 유의하 게 높은 것을 볼 수 있었다(Table 2). 여자군에서는 비교적 비 슷한 성향을 보이지만 통계학적으로 유의한 차이를 보이지 는 않았다. 앞서 나온 유의한 결과 중 신체의 성장지수를 표면 적으로 잘 나타내어 주는 체질량지수 $\left(\mathrm{kg} / \mathrm{m}^{2}\right)$ 를 기준으로 신 체와의 관계를 고려해보기 위해 각각의 연령대별로 나누어 비중격 만곡증과의 관계를 분석하였다(체질량지수는 18 미만 까지는 저체중, 18 25는 정상체중, 25 이상은 과체중으로 정 의하였다)(Table 3). 그 결과 10 20대 남성군에서 체질량지수 $\left(\mathrm{kg} / \mathrm{m}^{2}\right)$ 와 비중격 만곡증이 의미 있는 양의 상관관계를 가지 는 것으로 분석되었다(기존 조사군에 포함된 연령대가 13세 이상으로 정해져 있어 $\mathrm{n}$ 수로 인한 분석학적 차이를 줄이기 위 하여 10 대와 20대를 한 그룹으로 묶어 설정하였다). 이 결과 를 토대로 10 20대를 대상으로 하여 대표적인 영양소 섭취 를 분석한 결과 비중격 만곡증을 가지고 있는 남성군에서 칼슘을 제외한 나머지 영양소들은 모두 양의 상관관계를 가졌 으며, 그중에서도 총 에너지량, 1 일 단백질 섭취량, 1 일 지방의 섭취량은 통계학적으로도 유의하게 높은 것으로 분석되었다 (Table 4). 여자군에서도 비중격 만곡증이 있는 경우 지방, 철, 나트륨을 제외한 나머지 것들에서 양의 관계를 가졌으나 이들 은 모두 유의하지는 않았다.

요약해 보면 1) 신장 $(\mathrm{cm})$, 허리둘레 $(\mathrm{cm})$, 체질량지수 $\left(\mathrm{kg} / \mathrm{m}^{2}\right)$ 등을 성별로 나누어 비중격 만곡증의 유병률을 분석하였을 때 세 가지 모두 남자에서 의미 있는 양의 상관관계를 지닌다. 2) 체질량지수 $\left(\mathrm{kg} / \mathrm{m}^{2}\right)$ 를 이용하여 비만도와 비중격 만곡증의 유병률을 분석하였을 때 10 20대 남자군에서 유의하게 양의 상관관계를 가진다. 3) 10 20대 남자군에서 총 에너지 섭취량, 단백질, 지방의 섭취량이 많을수록 비중격 만곡증의 유병률 이 의미 있게 높았다라는 결과들이 분석되었다.

Table 1. Analysis of gender difference in all participants

\begin{tabular}{|c|c|c|c|c|}
\hline \multirow{2}{*}{ Variable } & \multicolumn{2}{|c|}{ Male (8636/43.8\%) } & \multicolumn{2}{|c|}{ Female (11049/56.1\%) } \\
\hline & W/NSD & w/O NSD & w/NSD & W/O NSD \\
\hline n (\%) & $4913(56.9)$ & $3723(43.1)$ & $4467(40.4)$ & $6582(59.6)$ \\
\hline
\end{tabular}

w/NSD: participants with nasal septal deviation, w/o NSD: participants without nasal septal deviation

Table 2. Relationship of septal deviation with height, waist circumference, and BMI

\begin{tabular}{|c|c|c|c|c|c|c|}
\hline \multirow{3}{*}{ Variables } & \multicolumn{2}{|c|}{ Male } & \multirow{3}{*}{ p-value } & \multicolumn{2}{|c|}{ Female } & \multirow{3}{*}{ p-value } \\
\hline & $\mathrm{W} / \mathrm{NSD}$ & W/O NSD & & W/NSD & w/O NSD & \\
\hline & Mean $\pm S D$ & Mean $\pm S D$ & & Mean $\pm S D$ & Mean $\pm S D$ & \\
\hline Height (cm) & $165.8 \pm 8.65$ & $163.7 \pm 8.38$ & $<0.001$ & $156.7 \pm 6.53$ & $156.6 \pm 6.66$ & 0.764 \\
\hline Waist circumference $(\mathrm{cm})$ & $79.08 \pm 10.3$ & $77.35 \pm 10.3$ & $<0.001$ & $77.91 \pm 10.2$ & $77.7 \pm 10.28$ & 0.542 \\
\hline $\mathrm{BMI}\left(\mathrm{kg} / \mathrm{m}^{2}\right)$ & $23.28 \pm 3.55$ & $22.94 \pm 3.62$ & $<0.001$ & $23.23 \pm 3.62$ & $23.16 \pm 3.58$ & 0.277 \\
\hline
\end{tabular}

W/NSD: participants with nasal septal deviation, w/o NSD: participants without nasal septal deviation, BMI: body mass index

Table 3. Septal deviation incidence according to age and BMI

\begin{tabular}{|c|c|c|c|c|c|c|c|c|}
\hline \multirow{2}{*}{ Variables } & \multicolumn{4}{|c|}{ Male } & \multicolumn{4}{|c|}{ Female } \\
\hline & Low & Moderate & High & $p$-value & Low & Moderate & High & $p$-value \\
\hline $10-20 \mathrm{yr}(13 \mathrm{yr}-)$ & 42.2 & 52.0 & 55.4 & 0.002 & 37.1 & 37.9 & 39.3 & 0.595 \\
\hline $30-39 \mathrm{yr}$ & 66.6 & 60.4 & 61.9 & 0.713 & 42.7 & 41.8 & 42.9 & 0.824 \\
\hline $40-49 \mathrm{yr}$ & 81.8 & 59.6 & 57.6 & 0.272 & 32.5 & 40.3 & 43.3 & 0.146 \\
\hline $50-59 \mathrm{yr}$ & 63.6 & 58.7 & 57.9 & 0.721 & 50.0 & 42.4 & 42.7 & 0.951 \\
\hline $60-69 \mathrm{yr}$ & 50.0 & 58.9 & 60.1 & 0.485 & 55.5 & 38.8 & 41.0 & 0.471 \\
\hline $70 \mathrm{yr}-$ & 44.2 & 54.1 & 56.2 & 0.193 & 39.6 & 39.2 & 38.4 & 0.734 \\
\hline
\end{tabular}

Data are expressed as percentage (\%). BMI ( $\left.\mathrm{kg} / \mathrm{m}^{2}\right)$ grading: low (low weight; - 18), moderate (normal weight; 18-25), high (over weight; 25-), BMl: body mass index, yr: year 
Association of Dietary Factors with Presence and Severity of Septal Deviation I Han C, et al.

Table 4. Analysis of nasal septal deviation between nutrients intake in 10-20 aged group

\begin{tabular}{|c|c|c|c|c|c|c|}
\hline \multirow[b]{2}{*}{ Variables } & \multicolumn{2}{|c|}{ Male } & \multirow[b]{2}{*}{ p-value } & \multicolumn{2}{|c|}{ Female } & \multirow[b]{2}{*}{$p$-value } \\
\hline & $\begin{array}{c}\text { W/NSD } \\
\text { Mean } \pm \text { SD }\end{array}$ & $\begin{array}{l}\text { w/o NSD } \\
\text { Mean } \pm \text { SD }\end{array}$ & & $\begin{array}{c}\text { W/NSD } \\
\text { Mean } \pm \text { SD }\end{array}$ & $\begin{array}{c}\text { W/O NSD } \\
\text { Mean } \pm \text { SD }\end{array}$ & \\
\hline Total intake (g) & $1612 \pm 768.7$ & $1570 \pm 765.3$ & 0.396 & $1279 \pm 588.3$ & $1236 \pm 535.6$ & 0.285 \\
\hline Energy intake (kcal) & $2574 \pm 1027$ & $2443 \pm 923.7$ & 0.036 & $1969 \pm 825.2$ & $1929 \pm 734.2$ & 0.476 \\
\hline Water (g) & $1027 \pm 603.3$ & $1014 \pm 618.2$ & 0.730 & $825.0 \pm 450$ & $794.4 \pm 410.4$ & 0.319 \\
\hline Protein (g) & $95.69 \pm 54.42$ & $89.39 \pm 43.43$ & 0.048 & $69.85 \pm 35.2$ & $69.38 \pm 34.60$ & 0.848 \\
\hline Fat (g) & $70.07 \pm 45.85$ & $64.22 \pm 40.63$ & 0.036 & $51.25 \pm 32.9$ & $52.06 \pm 31.12$ & 0.719 \\
\hline Carbohydrate (g) & $387.5 \pm 144.9$ & $373.6 \pm 133.6$ & 0.117 & $306.8 \pm 133$ & $296.6 \pm 114.4$ & 0.253 \\
\hline Fiber (g) & $6.519 \pm 4.507$ & $6.181 \pm 3.647$ & 0.202 & $5.237 \pm 4.04$ & $4.995 \pm 3.114$ & 0.359 \\
\hline $\mathrm{Ca}(\mathrm{mg})$ & $585.0 \pm 400.5$ & $591.0 \pm 393.4$ & 0.814 & $464.6 \pm 322$ & $451.1 \pm 280.0$ & 0.531 \\
\hline $\mathrm{P}(\mathrm{mg})$ & $1426 \pm 595.3$ & $1391 \pm 573.2$ & 0.343 & $1075 \pm 467.7$ & $1056 \pm 444.9$ & 0.560 \\
\hline $\mathrm{Fe}(\mathrm{mg})$ & $15.60 \pm 11.02$ & $14.65 \pm 9.951$ & 0.159 & $11.56 \pm 8.99$ & $12.03 \pm 8.206$ & 0.429 \\
\hline $\mathrm{Na}(\mathrm{mg})$ & $4941 \pm 2877$ & $4752 \pm 2606$ & 0.283 & $3638 \pm 2098$ & $3729 \pm 2191$ & 0.549 \\
\hline $\mathrm{K}(\mathrm{mg})$ & $3105 \pm 1528$ & $3021 \pm 1560$ & 0.392 & $2397 \pm 1172$ & $2373 \pm 1114$ & 0.761 \\
\hline
\end{tabular}

W/NSD: participants with nasal septal deviation, w/O NSD: participants without nasal septal deviation

\section{고 찰}

1960 1970년대와 비교하였을 시 우리나라의 식단은 확실히 총 에너지 섭취량과 단백질, 지방의 섭취량이 늘어났다. 이 변 화의 이유로는 근대화 및 산업화가 많이 이루어지며 개개인의 경제적 여유가 늘어남에 따라 섭취할 수 있는 음식이 다양해 지고 또 육류 등에 대해 접근성이 이전보다 높아졌을 뿐만 아니라 상대적으로 쌀, 밀 등을 포함한 곡류의 섭취가 많이 감소되었기 때문인 것으로 생각된다. ${ }^{710)}$ 비중격 만곡증의 유 병률 결과를 보자면 전반적으로 남자군과 여자군에서 비중 격 만곡증의 유병률 차이는 크지 않았으나 전체 유병률이 $47.5 \%$ 로 분석되었는데 이는 이전의 논문들에 따른 동양인에 서의 유병률인 $48 \%$ 와 비슷한 정도를 나타내고 있어 본 연구 데이터가 이전과 크게 다르지 않다는 것을 알 수 있다. ${ }^{9}$ 또한 성별로 나누어 키 $(\mathrm{cm})$, 허리둘레 $(\mathrm{cm})$, 체질량지수 $\left(\mathrm{kg} / \mathrm{m}^{2}\right)$ 의 결과에서 남성과 여성의 통계학적 유의성 차이를 보이는 것 은 상대적으로 여성군의 전반적인 신체 조건이 남성군보다 작아 그 분포가 넓지 않은 것을 원인으로 생각해볼 수 있겠 다. 나이별로 체질량지수 $\left(\mathrm{kg} / \mathrm{m}^{2}\right)$ 를 이용하여 분석하였을 때 남성군 10 20대에서 유의한 양의 상관관계를 가졌지만, 비 록 여성군 10 20대를 포함한 거의 대부분의 그룹에서 유의 하지는 않으나 양의 상관관계를 가지는 것으로 보아 비만 정 도와 비중격 만곡증의 유병률과의 관계도 추후에 연구해볼 가치가 있는 것으로 사료된다. 서양인들이 타 인종보다 nasal resistance가 높다고 한 연구들이 이전에 여러 차례 발표되기 도 하였으나 뚜렷한 이유에 대해서는 아직 알 수 없어 유전적 인종적 원인 이외에 식습관에 대해 그 차이를 이번 연구를 통 해 알아보려 하였다. ${ }^{11)}$ Nasal resistance를 증가시키는 요인 중
에 nasal orifice, pyriform aperture, nasal valve, upper alar cartilage, turbinate 등 해부학적 요인들이 알려져 왔으나 이 들을 실제 임상에서 확인하기 어렵다는 점에서 실제 임상에서 가장 손쉽게 확인 가능한 비중격 만곡증 여부로 환자의 nasal obstruction을 판단하기 위해 전 국민 영양설문지검사를 이용 한 후향성 검사라는 것에 의미를 두고 싶다. '서구화된 식단' 이라 정해진 것은 없으나, 한국인의 식단 형태가 상대적으로 탄수화물의 비율이 줄고 단백질의 비율이 늘어난 서양인들 의 영양 섭취 행태와 정도가 비슷해지는 것을 통해 이러한 결 과에 대해 의미를 가질 수 있을 것으로 사료된다. 본 연구결 과에 따르면 비중격 만곡증의 유병률은 한국에서는 10 20 대 남성군에서 체질량지수 $\left(\mathrm{kg} / \mathrm{m}^{2}\right)$ 가 높을수록, 총 에너지, 단백질, 지방의 섭취가 많을수록 유병률이 높게 분석되었는 데 이는 점차 서구화된 식단으로 인해 현재 영향을 가장 많이 받은 연령대가 10 20대인 것을 고려해볼 수도 있겠지만, 이 전의 연구를 살펴보면 젊은 남성들에게서 외상설과의 연관 성도 주장되고 있어 서구화된 식단만으로 단정 짓기 어려운 점 이 이번 연구의 한계점이라고 볼 수 있다. 또한 여성들에게서 도 10 20대의 body mass index가 제일 큰 연령대임에도 불 구하고 유의한 상관성이 없는 하나의 가능성으로도 여성들 이 남성들만큼 외상의 확률이 떨어져 유병률에 영향을 끼쳤 을 것으로 생각해볼 수 있다. 본 연구의 제한점은 이전에 실 시했던 조사결과를 바탕으로 후향적인 결과를 통해 분석된 것으로써 30 대 이상에서 비중격 만곡증과 다른 변수들과의 선후관계가 명확치 않고, 앞으로의 변화를 충분히 반영하는 것이 아니라는 점, 그리고 다양한 기관의 많은 수의 사람들 에게서 도출된 data로서 자료의 정확성이나 일관성이 떨어 질 수 있다는 점 등이 있다. 이런 제한점 등을 보완하여 data가 
나온다면 이를 통해 유사한 결론이 도출되어 추후 영양소 향 상에 따른 비만도를 더 세밀하게 분석해볼 필요가 있겠고 또 한 비만도를 통해 비중격 만곡증의 위험인자로서 삶의 질에 많은 영향을 끼치는 여러 증상들을 개선시키는 데에도 많은 도움이 될 것으로 생각된다.

\section{REFERENCES}

1) Mattos JL, Woodard CR, Payne SC. Trends in common rhinologic illnesses: analysis of U.S. healthcare surveys 1995-2007. Int Forum Allergy Rhinol 2011;1(1):3-12.

2) Cho YS, Choi SH, Park KH, Park HJ, Kim JW, Moon IJ, et al. Prevalence of otolaryngologic diseases in South Korea: data from the Korea national health and nutrition examination survey 2008. Clin Exp Otorhinolaryngol 2010;3(4):183-93.

3) Neskey D, Eloy JA, Casiano RR. Nasal, septal, and turbinate anatomy and embryology. Otolaryngol Clin North Am 2009;42(2):193-205.

4) Zielnik-Jurkiewicz B, Olszewska-Sosińska O. The nasal septum deformities in children and adolescents from Warsaw, Poland. Int J Pediatr Otorhinolaryngol 2006;70(4):731-6.

5) Mladina R, Cujić E, Subarić M, Vuković K. Nasal septal deformities in ear, nose, and throat patients: an international study. Am J Otolaryngol 2008;29(2):75-82.

6) Bhattacharyya N. Associations between obesity and inflammatory sinonasal disorders. Laryngoscope 2013;123(8):1840-4.

7) Mo SM. 외식산업의 발달이 국민영양 및 식생활에 미치는 영향. Korean J Nutr 1986;19(2):120-8.

8) Drewnowski A, Popkin BM. The nutrition transition: new trends in the global diet. Nutr Rev 1997;55(2):31-43.

9) Ahn JC, Kim JW, Lee CH, Rhee CS. Prevalence and risk factors of chronic rhinosinusitus, allergic rhinitis, and nasal septal deviation: results of the Korean national health and nutrition survey 2008-2012. JAMA Otolaryngol Head Neck Surg 2016;142(2):162-7.

10) Seo SH, Lee EJ, Kim JW. Nutrition transition in Korea and other countries. J Korean Elemen Educ 2008;19(1):31-55.

11) Ohki M, Naito K, Cole P. Dimensions and resistances of the human nose: racial differences. Laryngoscope 1991;101(3):276-8. 